Vol. 4, No. 1, Juni 2020, hal. 48-64

ISSN 2598-3245 (Print), ISSN 2598-3288 (Online)

DOI: http://doi.org/10.31961/eltikom.v4i1.170

Tersedia online di http://eltikom.poliban.ac.id

\title{
PENINGKATAN PERFORMA PREDIKSI DAERAH POTENSI PENANGKAPAN IKAN DENGAN METODE THRESHOLD ADAPTIF
}

\author{
Ridla Kumara Hadi, Rudy Hartanto, dan Silmi Fauziati \\ Departemen Teknik Elektro dan Teknologi Informasi, Universitas Gadjah Mada, Yogyakarta, Indonesia \\ e-mail: ridla.kumara.h@mail.ugm.ac.id, rudy@ugm.ac.id, silmi@ugm.ac.id
}

Diterima 4 Februari 2020 - Direvisi 11 Maret 2020 - Disetujui 16 Maret 2020

\begin{abstract}
The method for determining thermal fronts is the Single Image Edge Detection algorithm with a static threshold of 0.5 obtained from previous research. The flaw of this method is a high bias of detection accuracy because negative detection results are much more matched than the positive detection. The research aims to improve the performance of fish location potential detection. Thermal front detection performance improvement can be made by calculating fronts using an appropriate optimal threshold for each image. Adaptive threshold value obtained from analyzing histograms on each greyscale image. To obtain an optimal threshold value, Otsu Algorithm was chosen with consideration of fast process time and moderate accuracy. Method adjustment is needed since the nature of rasterized SST data. Otsu method modification was carried out on optimal threshold value calculation within greyscale intensities range 1-254. Geodesic buffering within the maximum range of 10 kilometers is used for overcoming the shifted first result from the noise suppression process. The result of this study is a method for detecting potential fish areas with a recall performance value of $25.42 \%$ higher than the static threshold method. A higher recall value proves that the proposed method able to produce more positive zone detection, which precise location compared with actual fishing data.
\end{abstract}

Keywords: adaptive threshold, edge detection, fishing ground prediction, performance analysis.

\section{ABSTRAK}

Metode yang digunakan untuk penentuan thermal fronts adalah algoritme Single Image Edge Detection dengan threshold statis 0,5 yang didapatkan dari penelitian terdahulu. Kekurangan dari metode threshold statis adalah tingginya bias akurasi hasil deteksi dikarenakan lebih banyaknya hasil deteksi negatif tervalidasi dibandingkan deteksi front murni yang tervalidasi. Penelitian yang diusulkan bertujuan untuk meningkatkan performa metode deteksi daerah potensi ikan. Peningkatan performa deteksi thermal front dapat dilakukan dengan mencari nilai threshold optimal yang sesuai untuk masing-masing citra. Threshold adaptif didapatkan dari hasil analisis histogram pada setiap citra greyscale yang diproses. Untuk mendapatkan nilai threshold optimal dipilih Algoritme Otsu dengan pertimbangan proses cepat dan ketepatan hasil menengah. Penyesuaian metode dibutuhkan karena sifat dasar data SST yang dikonversi menjadi raster. Modifikasi metode Otsu dilakukan pada perhitungan nilai threshold optimal dengan rentang intensitas greyscale 1-254. Pemurnian front menggunakan pendekatan Geodesic Buffering dengan jarak maksimal 10 kilometer untuk mengatasi pergeseran front akibat noise suppression. Penelitian telah dilakukan dan menghasilkan metode deteksi daerah potensi ikan dengan performa recall yang lebih tinggi 25,42\% dibandingkan metode threshold statis. Nilai recall lebih tinggi membuktikan bahwa metode yang diusulkan mampu menghasilkan lebih banyak hasil deteksi front murni yang lokasinya tervalidasi dengan data aktual penangkapan ikan.

Kata Kunci: analisis performa, deteksi tepi, prediksi daerah potensi penangkapan ikan, threshold adaptif.

\section{Pendahuluan}

$\mathrm{D}$ ISTRIBUSI kelimpahan sumber daya hayati pada laut bergantung pada kondisi dan variasi parameter oseanografi. Untuk pengelolaan sumber daya laut secara berkelanjutan diperlukanlah informasi yang lengkap dan akurat. Sebagai pilihan solusi dalam menentukan daerah 


\section{Jurnal ELTIKOM : Jurnal Teknik Elektro, Teknologi Informasi dan Komputer}

penangkapan ikan adalah dengan Sistem Informasi Geografis dan Penginderaan Jauh. Kombinasi solusi memperluas jangkauan perairan yang dianalisis daripada pengamatan langsung [1].

Di Indonesia penggunaan data citra satelit untuk prediksi daerah potensi penangkapan ikan dilakukan oleh instansi pemerintah yaitu Kementerian Kelautan dan Perikanan (KKP) dengan produk berupa informasi Peta Potensi Daerah Penangkapan Ikan (PPDPI), Lembaga Penerbangan dan Antariksa Nasional (LAPAN) dengan produk bernama Zona Potensi Penangkapan Ikan (ZPPI), dan Badan Pengkajian dan Penerapan Teknologi (BPPT) dengan produk berupa Sistem Informasi Knowledgebased Expert System Fishing Ground (SIKBES-FG) [2]. Pendekatan ekosistem melalui deteksi tepi data citra satelit digunakan untuk mendeteksi thermal front. Thermal front direferensi silang dengan tingkat klorofil yang sesuai untuk mendapatkan lokasi potensi lingkungan keberadaan ikan [3]. Thermal front diasosiasikan dengan upwelling yaitu penaikan masa air sehingga nutrien yang ada di dasar laut terbawa ke permukaan laut. Dataset citra diolah dan dilakukan identifikasi lokasi upwelling dengan dasar indikator klorofil-a yang tinggi dan Sea Surface Temperature (SST) yang rendah dari sekitarnya [4]. Hasil identifikasi lokasi akan disajikan dalam titik koordinat bujur dan lintang untuk nantinya dapat digunakan oleh kapal penangkap ikan sebagai acuan lokasi.

Sistem prediksi daerah potensi ikan PPDPI, SIKBES-FG dan ZPPI terbatas pada jenis ikan pelagis umum. Ikan pelagis menjadi komoditas dominan di Indonesia, menurut penelitian sekitar 75 persen dari produksi perikanan tangkap atau sekitar 4,8 juta ton per tahun dari perekaman data KKP [5][6]. Kelompok ikan pelagis adalah kelompok yang hidup dan mencari makan pada daerah perairan terbuka dan bebas dari dasar laut pada kedalaman hingga 200 meter dari permukaan [7]. Kelompok ikan pelagis dibagi berdasarkan ukuran yaitu: kelompok ikan pelagis besar seperti Tuna mata besar (Thunnus obesus), Madidihang (Thunnus albacares), Albakora (Thunnus alalunga), Cakalang (Katsuwonus pelamis); kelompok ikan pelagis sedang seperti Tongkol (Euthynnus Affinis); dan kelompok ikan pelagis kecil seperti Lemuru (Sardinella lemuru) [8]. Habitat ikan pelagis berada pada pertemuan suhu perairan optimum dengan ekosistem yang mengandung klorofil-a tinggi sebagai sumber makanan [1][9]. Menurut penelitian yang dilakukan Zainuddin [10] tentang tingkat klorofil-a habitat ikan Cakalang berada pada rentang nilai $0,15-0,4 \mathrm{mg} / \mathrm{m}^{3}$. Penelitian lain mengenai habitat ikan Cakalang pada musim lain berkisar pada tingkat klorofil-a $0,15-0,25 \mathrm{mg} / \mathrm{m}^{3}$ [11]. Sedangkan penelitian oleh Rintaka dan Susilo [12] menyarankan penggunaan nilai tingkat klorofil-a pada rentang $0,2-0,5 \mathrm{mg} / \mathrm{m}^{3}$.

Perekaman data penginderaan jauh menghasilkan data citra dalam format digital yang berarti citra tersebut terbentuk dari susunan nilai yang disebut piksel. Tetapi hanya citra saja belum berarti ada informasi yang dihasilkan, untuk itu perlu diintepretasikan untuk mengetahui informasi yang tekandung dalamnya. Dalam melakukan intepretasi diperlukan metode klasifikasi untuk mendapatkan perbedaan nilai piksel pada citra yang merepresentasikan obyek-obyek [13]. Klasifikasi citra digunakan untuk analisis pendekatan ekosistem dengan parameter fisika laut (suhu) dan parameter biologi (klorofil-a) [14]. Salah satu cara deteksi thermal front adalah dengan menerapkan algoritme deteksi tepi. Pada penelitian Cayula dan Cornillon threshold yang digunakan adalah $0.4^{\circ}$ Celcius, nilai optimal didapatkan dari penelitian di daerah Atlantik Utara [15]. Untuk saat ini nilai threshold algoritme Single Image Edge Detection (SIED) yang digunakan oleh institusi produsen deteksi daerah potensi penangkapan ikan di Indonesia adalah $0,5^{\circ}$ Celcius [16]. Nilai berdasarkan hasil studi identifikasi thermal front di Selat Makasar dan Laut Banda yang dijadikan rerata threshold perairan Indonesia [17].

Permasalahan utama dalam pengolahan citra adalah untuk mendapatkan informasi obyek pada citra kompleks agar dapat diartikan sebagai obyek yang sebenarnya. Segmentasi citra menjadi sangat sulit untuk citra yang didalamnya terdapat jarak antar nilai grey level yang luas. Informasi utama dari sebuah citra dapat direpresentasikan setidaknya 2 kelompok grey level. Kelompok pertama dikorespondensikan dengan obyek sedangkan kelompok kedua adalah latar belakang. Masing-masing kelompok akan memiliki puncak jika dilihat dari sebaran histogram intensitas pikselnya [18]. Dari perbedaan puncak histogram dapat ditarik sebuah threshold untuk membedakan nilai antara kelompok piksel obyek dengan background [19].

Citra sensor infrared yang bersih dengan kondisi optimal biasanya memiliki tepi yang panjang, berkesinambungan dan halus. Citra bersih dan optimal sangat sulit didapat, kebanyakan citra memiliki banyak noise, yang memiliki tepi buram, putus-putus dan pendek. Tantangan untuk penelitian dibidang 


\section{Jurnal ELTIKOM : Jurnal Teknik Elektro, Teknologi Informasi dan Komputer}

edge detection terhadap citra dengan banyak noise tersebut adalah pengembangan filter dan threshold untuk membersihkan noise dan untuk mendapatkan tepi yang optimal. Edge detection digunakan untuk mencari perubahan nilai dari kelompok piksel yang homogen yang tersambung pada suatu area dengan kelompok piksel homogen yang tersambung pada area bersebelahan. Untuk mendapatkan perbedaan antar area diperlukan threshold. Threshold dapat berupa sebuah batas minimal perbedaan nilai (standar) atau perbedaan nilai dalam range dengan nilai minimum dan maksimum (hysteresis) atau sebuah nilai tengah diantara pengelompokan (Otsu). Nilai threshold yang optimal akan dapat menyajikan hasil deteksi yang serupa dengan kondisi sebenarnya atau paling tidak mayoritas dari deteksi menyerupai kondisi sebenarnya. Threshold optimal dapat dicari dengan membandingkan nilai dari seluruh piksel pada citra dengan nilai threshold yang berbeda-beda, dengan hasil tepi yang panjang, kontinyu dan tipis [20].

Dalam penelitian Marcello dkk [21] melakukan evaluasi secara detil terhadap 36 teknik thresholding otomatis global dan lokal telah dilakukan dan tiap-tiap metode memiliki keunggulan pada kategori tertentu (histogram shape-based, clustering-based, entropy-based, object attribute-based, spatial methods, dsb.). Didapatkan hasil memuaskan untuk segmen struktur permukaan laut yang dicapai dengan teknik Riddler, Otsu, Gaussian Mixture Modeling, Pun atau Li. Secara khusus, algoritme Otsu menyediakan solusi menengah, akurat, dan dapat dipilih sebagai teknik yang tepat, memberikan hasil yang sangat baik untuk sebagian besar citra.

Pengembangan algoritme combination multiple windows (CMW) adalah pemutakhiran algoritme SIED yang dilakukan dengan menambahkan grids pada proses moving windows algoritme SIED. Thermal front akan terdeteksi jika piksel yang berada pada grid lebih dari separuh. Algoritme SIED standarnya dilakukan pada citra dengan skala $1 \mathrm{~km}(1$ piksel mewakili area $1 \times 1 \mathrm{~km})$. Citra thermal laut dengan skala menengah digunakan untuk analisis dikarenakan dapat dilakukan proses yang lebih cepat, skala yang digunakan adalah $4 \mathrm{~km}(1$ piksel mewakili area $4 \times 4 \mathrm{~km})$. Tujuan penelitian adalah untuk membuat sebuah pra-pemrosesan yang cocok untuk citra skala $4 \mathrm{~km}$ tanpa mengurangi informasi yang relevan seperti front yang kecil [22].

Penelitian dilakukan untuk membangun sebuah algoritme dengan langkah awal melakukan interpolasi data citra satelit sparse (yang tertutup awan) dan selanjutnya penghalusan kontur dengan filter Gaussian $3 \times 3$. Algoritme yang dikembangkan adalah Microcanonical Multiscale Formalism (MMF), yaitu menghitung singularity exponent hingga pecahan terkecil pada citra. Untuk mencari thermal front, dilakukan metode penguatan pada pecahan terkecil tersebut dengan mencari rata-rata, pemberian threshold dan memperbaharui nilai piksel. Dalam ekstraksi lokasi thermal front yang masih didapatkan terlalu tebal maka dilakukan penentuan threshold manual berdasarkan kerapatan piksel. Hasilnya algoritme MMF mampu menampilkan hampir seluruh thermal front yang ada, tetapi tidak memenuhi kebutuhan akurasi lokasi [23]. Pengembangan selanjutnya dengan menambahkan deep learning menggunakan Convolutional Neural Network. Sebelumnya data akan melalui pra-pemrosesan dengan menggunakan AlexNet. Hasilnya lebih memuaskan dari segi akurasi, jika direduksi sejumlah deteksi false alarm pada area yang berbatasan dengan daratan [24].

Algoritme pencarian thermal front tradisional populer menggunakan edge detection dengan

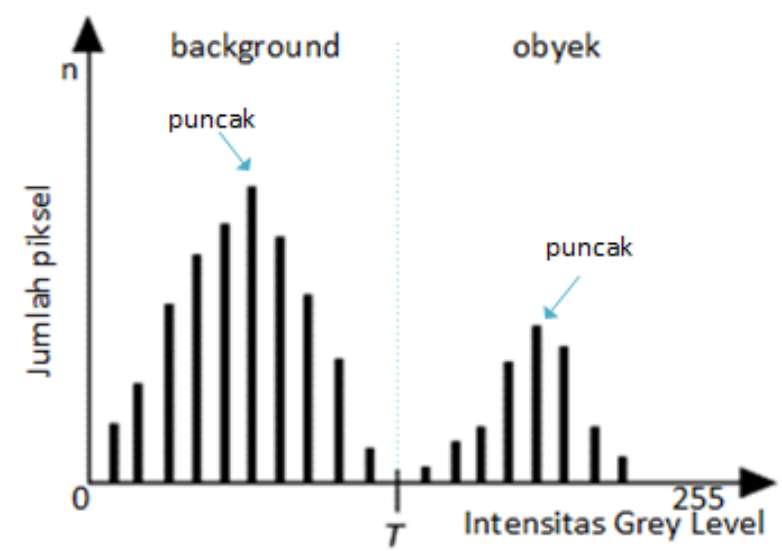

Gambar. 1. Histogram dua puncak (bimodal) citra grey level dengan Threshold (T) sebagai pemisah antara obyek dengan latar belakang. 


\section{Jurnal ELTIKOM : Jurnal Teknik Elektro, Teknologi Informasi dan Komputer}

pendekatan gradient (Canny) [25] dan histogram (Cayulla-Cornillon) [15]. Penelitian berikut melakukan kombinasi dari algoritme Canny dengan Cayula-Cornillon. Thermal front citra AVHRR yang dideteksi kedua algoritme akan diproses lebih lanjut pada sebuah Matching Module. Modifikasi dilakukan terhadap algoritme, yaitu penggunaan operator Sobel digantikan dengan operator Scharr, lalu dilakukan modifikasi non-maximum suppression untuk mendapatkan front yang optimal, dan penambahan iterasi terhadap ukuran window ketika menjalankan proses algoritme histogram [26].

Pengembangan metode baru untuk deteksi thermal front upwelling dilakukan oleh Oerder dkk. [27] terhadap data Multi-scale Ultra-high Resolution (MUR) SST, dengan menggunakan analisis histogram dan memperhitungkan piksel dekat pantai daerah yang terdampak Eastern Boundary Upwelling Systems (EBUS). Hasil dari penelitian dibandingkan dengan front detection metode SIED oleh Cayula-Cornillon [20]. Hasilnya adalah 120 citra dengan front yang relevan dari 180 citra terdeteksi front.

Dari studi penelitian terkait diatas dapat disimpulkan bahwa penggunaan metode deteksi SIED memiliki keunggulan lebih fleksibel dalam menentukan variabel untuk deteksi thermal front permukaan laut dibandingkan algoritme lainnya. Algoritme SIED menggunakan analisis histogram bimodal untuk menentukan thermal front. Kekurangan dari algoritme SIED adalah dalam penentuan nilai variabel threshold untuk perhitungan deteksi harus dilakukan penelitian karakteristik oseanografi terhadap area studi. Studi dan observasi secara in situ komprehensif membutuhkan banyak sumberdaya. Penelitian yang diusulkan bertujuan untuk meningkatkan performa metode deteksi daerah potensi ikan dengan pendekatan penentuan nilai threshold adaptif berbasis varians dan untuk mengatasi bergesernya tepi dengan menggunakan proximity analysis geodesic buffer.

\section{Metode Penelitian}

Metode deteksi thermal front yang digunakan saat ini menggunakan threshold statis 0,5 untuk setiap dataset yang diproses. Analisis menggunakan threshold statis mengakibatkan hasil deteksi daerah potensi penangkapan ikan mengalami bias pada akurasinya. Usulan metode penelitian yang akan digunakan untuk meningkatkan performa prediksi daerah potensi ikan adalah dimutakhirkan dengan pendekatan pra-pemrosesan menggunakan metode berbasis varians untuk mendapatkan nilai threshold adaptif. Keunggulan yang ditawarkan metode threshold berbasis varians adalah penggunaan analisis histogram bimodal dan penggunaan varians 2 populasi sesuai dengan algoritme SIED. Untuk mengatasi

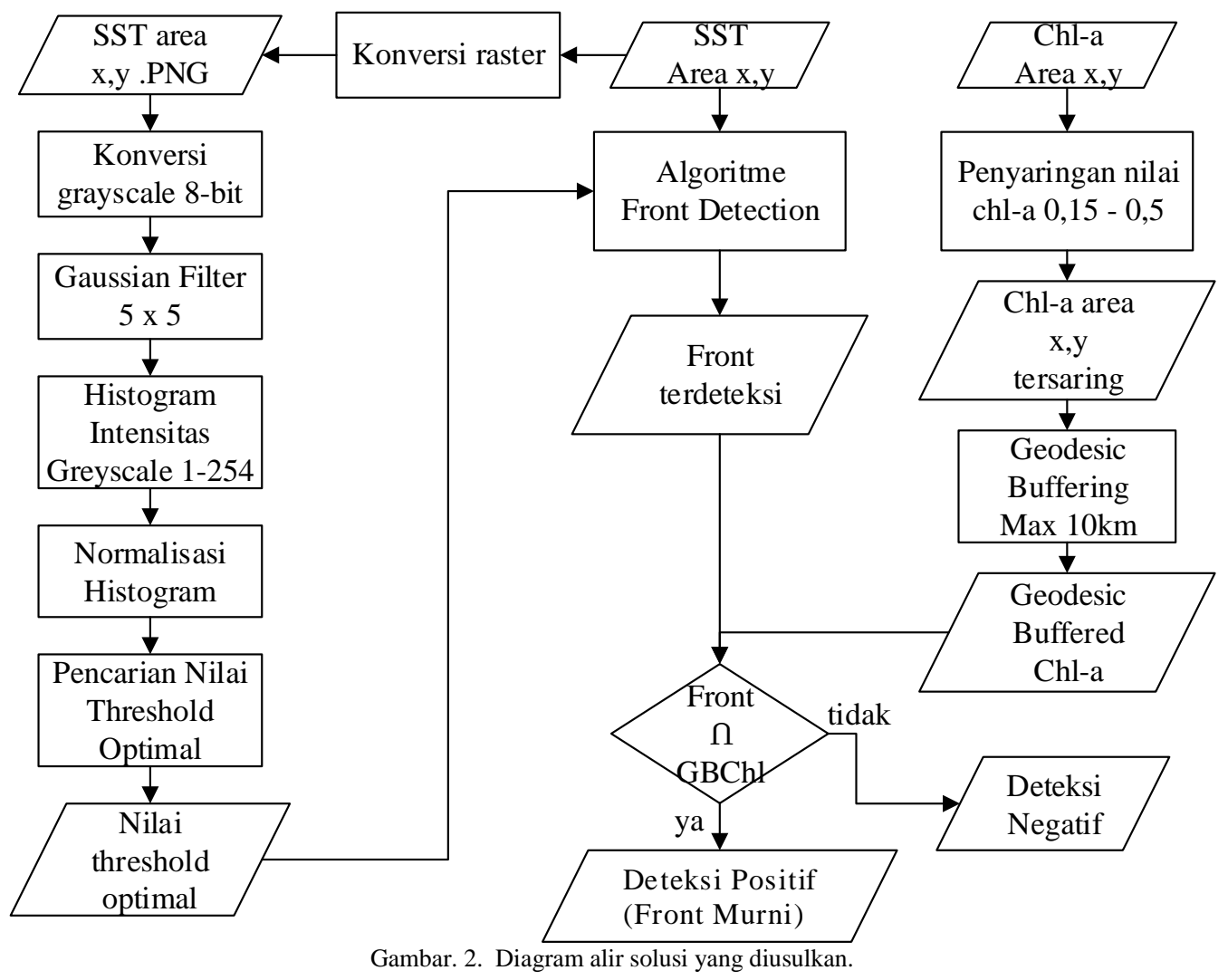




\section{Jurnal ELTIKOM : Jurnal Teknik Elektro, Teknologi Informasi dan Komputer}

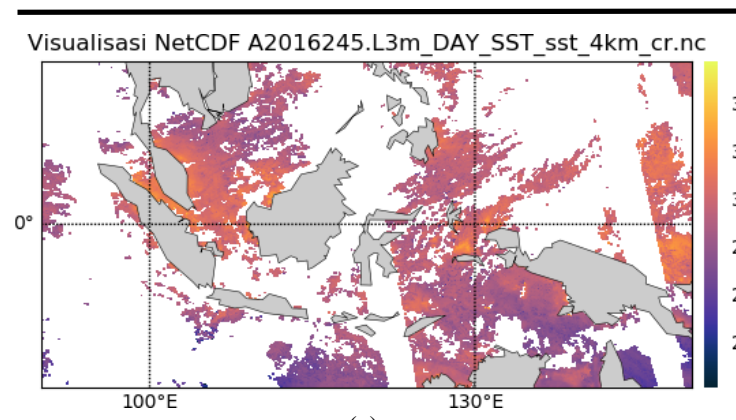

(a)

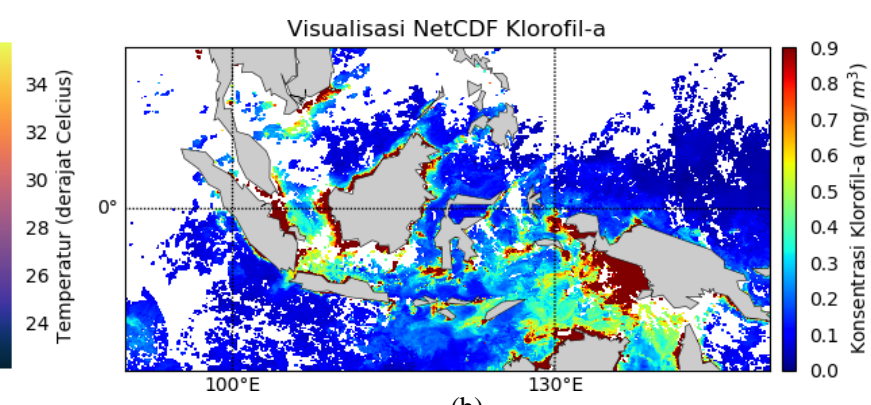

Gambar. 3. (a) Visualisasi dataset Sea Surface Temperature, (b) Visualisasi dataset Klorofil-a.

pergeseran tepi akibat proses noise suppression berupa Gaussian Filter dari metode berbasis varians, digunakan pendekatan pasca-pemrosesan menggunakan analisis Geodesic Buffering terhadap tepi atau front yang ditemukan. Metode usulan diterapkan pada penelitian dengan langkah-langkah berikut.

\section{A. Identifikasi Data}

\section{1) Dataset SST MODIS}

Sensor Moderate Resolution Imaging Spectroradiometer (MODIS) memiliki resolusi spektral lebih tinggi dibandingkan pendahulunya Advanced Very-High-Resolution Radiometer (AVHRR). MODIS memiliki total 36 pita spektral, dengan lebar swath $2330 \mathrm{~km}$ dan resolusi spasial bervariasi tiap sensornya dari $250 \mathrm{~m}$ hingga $1 \mathrm{~km}$. Satelit Terra dan Aqua sebagai wahana MODIS memiliki revisit time 1-2 hari sehingga memungkinkan untuk sensor dapat merekam pada siang dan malam hari untuk sebuah lokasi [28]. Sensor infrared MODIS untuk citra Sea Surface Temperature (SST) memiliki lebar kanal 3,5 $\mu \mathrm{m}$ sampai 4,2 $\mu \mathrm{m}$ (kanal 20 - 23) dan $10 \mu \mathrm{m}$ sampai $12 \mu \mathrm{m}$ (kanal 31 dan 32). Selain itu data citra MODIS disediakan turunannya berupa data level-3 yang tergolong ringan sehingga lebih mudah dan cepat untuk dianalisis seperti divisualisasikan pada Gambar 3(a). MODIS dikembangkan dengan resolusi spasial dan resolusi spektral yang lebih tinggi. Sebagai perbandingan kanal 4 sensor AVHRR memiliki lebar interval $10,30 \mu \mathrm{m}$ sampai dengan $11,30 \mu \mathrm{m}$, sedangkan kanal 31 sensor MODIS memiliki lebar interval 10,780 sampai dengan 11,280 [29][30][31].

Dataset SST level-3 global adalah turunan dari sensor MODIS yang beroperasi pada satelit NASA Terra dan Aqua. Untuk produk SST mid-infrared level-3 diturunkan dari kanal 20, 21, 22 dan 23. Produk thermal infrared level-3 diturunkan dari kanal 31 dan 32. Dataset SST siang (daytime) dan malam (nighttime) tersedia secara harian, mingguan (8 hari), bulanan atau tahunan dengan resolusi spasial 4,63 km maupun 9,26 km [28].

Penelitian akan menggunakan dataset long-wave SST daytime (menggunakan kanal 31 dan 32 pada 11 $\mu \mathrm{m}$ dan $12 \mu \mathrm{m}$ ) dikarenakan short-wave SST (menggunakan kanal 22 dan 23 pada 3,959 $\mu \mathrm{m}$ dan 4,050 $\mu \mathrm{m})$ terpengaruh oleh sinar matahari [28][32]. Kontaminasi tersebut menyebabkan dataset short-wave tidak dianggap valid untuk kebutuhan operasional analisis daerah potensi perikanan yang berlangsung di waktu pagi hari.

Dataset level-3 yang akan digunakan memiliki resolusi $4 \mathrm{~km}$ seperti terlihat pada Gambar 3(a), adalah turunan dari variable geofisika level-2 resolusi $1 \mathrm{~km}$ yang diproses dengan algoritme agregasi dan diproyeksikan ke dalam grid spasial. Keseluruhan proses dirumuskan oleh Ocean Biology Processing Group, NASA Goddard Space Flight Center [33]. Metode agregasi area homogen yang digunakan serupa dengan penelitian Sun dkk. [24]. Dataset MODIS level-3 dapat diakses dan diunduh melalui alamat tautan https://oceancolor.gsfc.nasa.gov/13/.

\section{2) Dataset Klorofil-a MODIS}

Dataset MODIS Klorofil-a didapatkan berdasarkan kalkulasi empiris yang diturunkan dari pengukuran in situ chlor_a dan penginderaan jauh yaitu pantulan spektrum warna bagian antara biru ke hijau. Nilai hasil kalkulasi akan mendeteksi konsentrasi klorofil-a (dalam satuan $\mathrm{mg} / \mathrm{m}^{3}$ ) diperairan mendekati permukaan seperti terlihat pada Gambar 3(b), deteksi tergantung keberadaan nilai pantulan setidaknya dua hingga empat kanal (kanal nomor 9 sampai dengan 13 dengan lebar 440 - $670 \mathrm{~nm}$ ) pada lokasi yang sama [34]. 


\section{Jurnal ELTIKOM : Jurnal Teknik Elektro, Teknologi Informasi dan Komputer}

Konsentrasi klorofil-a diukur secara in situ menggunakan instrumen optis fluorometer. Instrumen terdiri dari tiga light emitting diodes (LED) yang memancarakan energi gelombang cahaya eksitasi pada $435 \mathrm{~nm}, 470 \mathrm{~nm}$ dan $532 \mathrm{~nm}$. Digunakan sebuah detektor fotodioda untuk mengukur emisi fluoresensi klorofil pada $695 \mathrm{~nm}$. Panjang gelombang cahaya eksitasi dipilih untuk untuk memberikan isolasi terhadap in vivo absorbsion dari intensitas fluoresensi klorofil-a yang dihasilkan langsung dari energi eksitasi klorofil $(435 \mathrm{~nm})$ dan dari transfer energi dari klorofil lainnya, carotenoids, dan phycobilipigments. Cahaya eksitasi memasuki air pada sudut 55-60 derajat, cahaya berfluoresensi diterima pada sudut penerimaan 140 derajat. Digunakan filter interferensi untuk menolak cahaya eksitasi yang tersebar. Pembacaan tegangan voltase diubah menggunakan faktor skala menjadi nilai yang mewakili konsentrasi klorofil [35].

Produk klorofil-a didapatkan dari kombinasi algoritme O'Reilly band ratio OCx dan algoritme $\mathrm{Hu}$ color index (CI). Algoritme CI memanfaatkan perbedaan dua hingga empat gelombang dengan panjang antara 440 hingga $670 \mathrm{~nm}$ pada pita hijau. Sebagai tambahan sebuah referensi linier dibentuk dengan panjang gelombang yang sama pada pita biru dan merah [30][34].

3) Data Respon Balik PPDPI

Penentuan tanggal dan area dataset yang digunakan pada penelitian akan didasarkan pada data aktual penangkapan (respon balik peta prakiraan daerah penangkapan ikan) dari Balai Riset dan Observasi Laut KKP. Data respon balik peta prakiraan daerah penangkapan ikan adalah data laporan titik penangkapan ikan yang dilakukan kapal penangkapan ikan dengan ukuran lebih dari 25 Gross Ton. Titik penangkapan dilaporkan kepada petugas data entry respon balik penangkapan di setiap pelabuhan perikanan. Respon balik digunakan oleh Balai Riset dan Observasi Laut untuk validasi PPDPI [3]. Data respon balik berisi sebagian informasi dari log book operasional penangkapan ikan. Berdasarkan Peraturan Menteri Kelautan dan Perikanan Republik Indonesia Nomor 48 Tahun 2014 tentang log book penangkapan ikan, pada pasal 14 disebutkan bahwa data log book sifatnya adalah rahasia [36]. Sifat rahasia mengakibatkan data respon balik tidak lagi dapat digunakan oleh Balai Riset dan Observasi Laut untuk validasi PPDPI semenjak tahun 2017. Data respon balik peta prakiraan daerah penangkapan ikan yang telah dikumpulkan hingga tahun 2016 masih dapat digunakan dikarenakan sebelumnya telah menjadi bagian dari publikasi.

Area dataset yang akan dianalisis adalah dataset bulan September tahun 2016 pada Pelabuhan Perikanan Nusantara Kejawanan dengan area jelajah kapal penangkapan ikan meliputi Laut Jawa dan Selat Karimata. Batas area studi yang digunakan pada dataset adalah Tabel 1.

TABEL 1

BATAs AREA StUdi DATASET

\begin{tabular}{ccccc}
\hline \hline Batas & Barat & Utara & Selatan & Timur \\
\hline Koordinat (Decimal Degree) & 105,0 & $-2,0$ & $-7,0$ & 116,0 \\
\hline \hline
\end{tabular}

Nama file dataset untuk masing-masing dataset SST maupun klorofil-a adalah menggunakan standar penamaan dengan prefiks A2016245 (1 September 2016) hingga A2016265 (21 September 2016). Pemotongan area dataset meliputi area dengan batas pada Tabel 1 akan menghasilkan 264 kolom $\times 216$ baris data.

\section{B. Pencarian Threshold Adaptif Berbasis Varians}

Teknik yang berkaitan dengan penelitian yaitu segmentasi berdasar region menggunakan thresholding. Inti dari penggunaan thresholding adalah deteksi kemiripan piksel dan pengelompokan piksel yang masih berhubungan pada area yang terbatas. Ciri utama dari citra dapat direpresentasikan sebagai dua tingkat keabuan. Dengan kontras latar belakang (hitam) dan obyek (putih) yang dapat digambarkan dalam sebuah histogram bimodal (dua puncak), puncak pertama adalah kelompok piksel latar belakang (hitam) sedangkan puncak kedua adalah kelompok piksel obyek (putih). Seperti terlihat pada Gambar 1 dari perbedaan puncak dapat ditarik sebuah threshold untuk membedakan nilai antara kelompok piksel obyek dengan background [19].

Salah satu teknik penentuan segmentasi adalah penggunaan pengaturan threshold yang tepat [37]. Pada global thresholding menggunakan nilai threshold dengan perkiraan, sehingga tidak diketahui bahwa nilai yang digunakan tersebut sebenarnya dapat diimplementasikan atau tidak. Setidaknya harus melakukan trial dan error berulang kali untuk mendapatkan hasil terbaik [38]. 


\section{Jurnal ELTIKOM : Jurnal Teknik Elektro, Teknologi Informasi dan Komputer}

Citra bimodal adalah citra yang memiliki dua puncak pada histogramnya, dengan adanya dua puncak tersebut dapat diambil kesimpulan bahwa untuk mendapatkan batas perbedaan antar piksel bisa digunakan nilai tengah diantara dua puncak tersebut. Metode Otsu binarization akan melakukan perhitungan otomatis dari histogram pada sebuah citra bimodal. Data citra akan mengalami proses konversi grayscale, dikarenakan pada grayscale histogram biasanya memiliki dua puncak (bimodal) [39][40].

Pada sebuah citra bimodal, algoritme Otsu melakukan training untuk mendapatkan nilai threshold (t) yang didapatkan dari relasi weighted within-class variance. Untuk nilai threshold cukup berikan nilai nol dan algoritme akan melakukan pencarian optimal threshold untuk dikembalikan sebagai output kedua [41].

Pada algoritme Otsu keseluruhan piksel pada citra direpresentasikan sebagai $L$ derajat keabuan akan terlihat pada deret sebagai $[1,2, \ldots, L]$. Jumlah piksel pada titik $i$ dinotasikan sebagai $n_{i}$ dan jumlah total piksel dengan $N=n_{1}+n_{2}+. .+n_{L}$. Histogram derajat keabuan ternormalisasi dianggap sebagai distribusi probabilitas dengan persamaan sebagai berikut:

$$
P_{(i)}=\frac{n_{i}}{N}, \quad P_{(i)} \geq 0, \sum_{i=1}^{L} P_{(i)}=1
$$

Persamaan 1 diatas adalah sifat-sifat mutlak probabilitas pada titik $i\left(P_{(i)}\right)$ dengan peluang pada titik $i$ adalah jumlah piksel pada titik $i$ berbanding total keseluruhan piksel yang kemungkinannya pasti lebih dari atau sama dengan 0 dan jumlah keseluruhan probabilitas adalah 1. Untuk mendapatkan distribusi $i$ yang lebih merata, filter Gaussian akan diterapkan sebelum citra dinormalisasi. Jika direpresentasikan kelas piksel $b_{1}$ dan $b_{2}$ yang dipisahkan oleh threshold pada titik $k$ maka akan didapatkan deret $b_{1}[1, . ., k]$ dan $b_{2}[k+1, . ., L]$. Probabilitas $\left(P_{(i)}\right)$ terjadinya masing-masing kelas piksel adalah:

$$
\begin{gathered}
b_{1}=\sum_{i=1}^{k} P_{(i)} \text { atau } b_{1}=b(k) \\
b_{2}=\sum_{i=k+1}^{L} P_{(i)} \text { atau } b_{2}=1-b(k)
\end{gathered}
$$

dan tingkat rata-rata $(\mu)$ keseluruhan kelas adalah:

$$
\mu(k)=\sum_{i=1}^{k} i P_{(i)}
$$

sehingga didapatkan untuk rata-rata untuk masing-masing kelas adalah:

$$
\begin{gathered}
\mu_{1}=\sum_{i=1}^{k} \frac{i P_{(i)}}{b_{1}} \text { atau } \mu_{1}=\frac{\mu(k)}{b(k)} \\
\mu_{2}=\sum_{i=k+1}^{L} \frac{i P_{(i)}}{b_{2}} \text { atau } \mu_{2}=\frac{\mu_{T}-\mu(k)}{1-b(k)}
\end{gathered}
$$

Dalam ilmu statistik jika sebuah fungsi adalah suatu distribusi probabilitas maka momen ke 0 adalah total dari probabilitas, momen kesatu adalah rata-rata dan momen kedua adalah varians. Pada Persamaan 2 dan Persamaan 3 diatas $b(k)$ adalah momen kumulatif ke 0 dan pada Persamaan 4, Persamaan 5, dan Persamaan $6, \mu(k)$ adalah momen kumulatif kesatu pada histogram hingga titik k. Sedangkan $\mu_{T}=$ $\mu(L)$ adalah total rerata dari citra orisinil.

Varians $\left(\sigma^{2}\right)$ dari tiap kelas adalah momen kumulatif ke 2 yang dapat diturunkan dari Persamaan 5 


\section{Jurnal ELTIKOM : Jurnal Teknik Elektro, Teknologi Informasi dan Komputer}

dan Persamaan 6 sehingga didapatkan varians kelas pertama pada Persamaan 7 dan varians kelas kedua pada Persamaan 8 berikut:

$$
\begin{gathered}
\sigma_{1}^{2}=\sum_{i=1}^{k}\left(i-\mu_{1}\right)^{2} \frac{i P_{(i)}}{b_{1}} \\
\sigma_{2}^{2}=\sum_{i=k+1}^{L}\left(i-\mu_{2}\right)^{2} \frac{i P_{(i)}}{b_{2}}
\end{gathered}
$$

Untuk setiap pilihan nilai $k$ dapat dilakukan pembuktian dengan:

$$
b_{1} \mu_{1}+b_{2} \mu_{2}=\mu_{T}, b_{1}+b_{2}=1
$$

Berdasarkan pembuktian pada Persamaan 9 maka akan didapatkan perhitungan varians sebagai berikut:

$$
\begin{gathered}
\sigma_{b}^{2}=b_{1} \sigma_{1}^{2}+b_{2} \sigma_{2}^{2} \\
\sigma_{X}^{2}=b_{1}\left(\mu_{1}-\mu_{T}\right)^{2}+b_{2}\left(\mu_{2}-\mu_{T}\right)^{2}=b_{1} b_{2}\left(\mu_{2}-\mu_{1}\right)^{2} \\
\sigma_{T}^{2}=\sigma_{b}^{2}+\sigma_{X}^{2}=\sum_{i=1}^{L}\left(i-\mu_{T}\right)^{2} P_{(i)}
\end{gathered}
$$

dengan Persamaan 10 adalah varians didalam kelas piksel, Persamaan 11 adalah varians antar kelas piksel, dan Persamaan 11 adalah total varians dari tingkatan dalam kelas dan antar kelas. Nilai $\sigma_{b}^{2}, \sigma_{X}^{2}$ dan $\sigma_{T}^{2}$ akan digunakan untuk melakukan evaluasi bagus tidaknya threshold pada titik $k$, menggunakan analisis diskriminan dengan kriteria untuk pengukuran kelas secara terpisah, kriteria diskriminan yang digunakan adalah :

$$
\lambda=\frac{\sigma_{X}^{2}}{\sigma_{b}^{2}}, \quad \kappa=\frac{\sigma_{T}^{2}}{\sigma_{b}^{2}}, \quad \eta=\frac{\sigma_{X}^{2}}{\sigma_{T}^{2}}
$$

Kriteria analisis diskriminan Persamaan 13 memaksimalkan $\lambda, \kappa$ dan $\eta$ untuk setiap nilai $k$, dan masing-masing setara satu sama lain. Fungsi maksimisasi akan setara dengan minimasi, sebagai contoh jika berdasarkan $\lambda, \kappa=\lambda+1$ dan $\eta=\lambda /(\lambda+1)$. Aturan relasi dasar Persamaan 14 yang selalu berlaku:

$$
\sigma_{b}^{2}+\sigma_{X}^{2}=\sigma_{T}^{2}
$$

Sebagai catatan bahwa $\sigma_{b}^{2}$ dan $\sigma_{X}^{2}$ adalah fungsi dari threshold pada titik $k$, tetapi $\sigma_{T}^{2}$ adalah fungsi yang terlepas dari nilai $k$. Diketahui juga bahwa $\sigma_{b}^{2}$ adalah berdasarkan statistik momen ke 2 (varians), sedangkan $\sigma_{X}^{2}$ adalah berdasarkan statistik momen ke satu (rerata kelas). Dapat disimpulkan $\eta$ adalah pengukuran paling sederhana berkenaan dengan nilai $k$. Kriteria $\eta$ akan digunakan untuk mengevaluasi bagus tidaknya sebuah threshold pada titik $k$.

Threshold optimal pada titik $k$ yang memaksimalkan $\eta$ atau sama dengan $\sigma_{X}^{2}$ akan dipilih dalam perhitungan berurutan dengan menggunakan kumulatif sederhana dari Persamaan 2 sampai dengan Persamaan 6 dan disimpulkan pada Persamaan 15 berikut:

$$
\eta(k)=\frac{\sigma_{X}^{2}(k)}{\sigma_{T}^{2}}
$$

Dengan $\eta(k)$ adalah kriteria diskriminan 3 pada threshold $k$ dan $\sigma_{X}^{2}(k)$ adalah varians antar kelas piksel dengan threshold $k$ sehingga untuk mencari $\sigma_{X}^{2}(k)$ sebagai varians antar kelas piksel yang terdapat 


\section{Jurnal ELTIKOM : Jurnal Teknik Elektro, Teknologi Informasi dan Komputer}

threshold optimal dengan Persamaan 16:

$$
\begin{gathered}
\sigma_{X}^{2}(k)=\frac{\left[\mu_{T} b(k)-\mu(k)\right]^{2}}{b(k)[1-b(k)]} \\
\sigma_{X}^{2}\left(k^{n}\right)=\max _{1 \leq \mathrm{k}<\mathrm{L}} \sigma_{X}^{2}(k)
\end{gathered}
$$

Threshold optimal pada titik $k^{n}$ adalah $\sigma_{X}^{2}\left(k^{n}\right)$ dari citra grayscale 8-bit yang berada pada nilai 0-255. Penggunaan umum perhitungan nilai threshold berada pada rentang lebih dari 0 (latar belakang) dan kurang dari 1 (obyek). Perkiraan pencarian maksimum $k$ pada Persamaan 16 dapat dibatasi nilainya menjadi $0<b(k)<1$, yang didapat dari sifat mutlak atau dapat disebut juga rentang nilai efektif dari histogram derajat keabuan [40].

\section{Deteksi Thermal Front Algoritme Single Image Edge Detection}

Algoritme Single Image Edge Detection Histogram Analysis menggunakan operator segmentasi lokal (boundary) dan regional. Ciri yang dideteksi dari front suhu adalah step edge. Untuk pendekatan regional, tepi yang dibutuhkan biasanya tipis sebagai pemisah antara dua area dengan suhu konstan yang berbeda. Untuk menghasilkan tepian tersebut dibutuhkan dua populasi piksel yang mewakili dua area yang diuji. Sedangkan pendekatan lokal menggunakan ukuran dan bentuk untuk secara bertahap memisahkan dua populasi piksel [42].

Algoritme SIED bekerja pada 3 level, yaitu level citra, level window dan level lokal. Sensor infrared beroperasi pada rentang spektrum thermal tidak dapat merekam menembus awan dan menjadikan tutupan awan sebagai permasalahan dalam analisis data maupun deteksi tepi. Hal tersebut mengakibatkan algoritme menggunakan langkah pra-pemrosesan untuk deteksi tutupan awan dan noise pada level citra dan level window.

Proses pada level citra dilakukan dengan 4 langkah. Langkah pertama adalah menggunakan simple thresholding untuk menandai daerah noise dan tutupan awan.

Langkah kedua didasarkan pada karakteristik daerah berawan yang menutupi permukaan laut menjadikan area dengan magnitudo gradien tinggi.

Langkah ketiga dari algoritme akan menerapkan threshold suhu untuk membedakan area tanpa tutupan awan dengan area terindikasi tertutup awan atau tertutup noise. Vektor gradien yang dianggap berada dalam area tutupan awan tidak memiliki arah koheren. Dalam penelitian terkait area dengan rasio jumlah magnitudo gradien kurang dari 0,3 ditandai sebagai area yang pasti tertutup awan, sedangkan untuk rasio lebih dari 0,7 diasumsikan sebagai area yang bersih dari noise maupun tutupan awan. Threshold kemudian digunakan untuk area dengan rasio antara 0,3 hingga 0,7 untuk mencari rasio aspek dengan membagi nilai eigen yang lebih besar dari matrik spasial kovarian dengan nilai eigen yang lebih kecil, jika nilai lebih besar dari 6 maka akan ditandai sebagai area bersih.

Langkah terakhir pada proses level citra adalah menerapkan Median Filtering $3 \times 3$ dan menghapus noise atau tutupan awan yang telah ditandai [15].

Untuk memisahkan gradien tinggi yang disebabkan tutupan awan dengan gradien tinggi yang disebabkan tepi yang sebenarnya, citra akan di segmentasikan menjadi window yang tumpang tindih dan akan diterapkan analisis histogram. Analisis histogram dilakukan pada sebuah window $32 \times 32$ piksel, jika ditemukan distribusi suhu (histogram) bimodal maka dapat ditentukan dua populasi dan variabilitas dalam setiap populasi dapat dianalisis secara terpisah dari kaitannya terhadap tepi [15][43]. Jika threshold optimal telah diketahui maka parameter seperti rerata dan varians untuk setiap populasi akan mudah dihitung. Varians akan digunakan algoritme korelasi untuk deteksi tutupan awan pada proses berikutnya [15].

Proses level window selanjutnya deteksi tutupan awan yang sebenarnya menggunakan algoritme korelasi untuk mengukur variabilitas suhu dengan estimasi fungsi otomatis korelasi dan kovarian. Metode deteksi tutupan awan menggunakan sumberdaya komputasi tinggi. Fungsi otomatis korelasi yang rumit harus didefinisikan untuk setiap populasi piksel [44]. Untuk mempermudah dan mempercepat komputasi dilakukan penyederhanaan dengan menggunakan nilai rerata perbedaan absolut populasi piksel [15]. 
Sebagai proses utama pada algoritme SIED adalah deteksi tepi pada level window dengan menggunakan analisis histogram. Signal to noise ratio citra setidaknya bernilai 4 untuk tingkat kepastian hasil yang lebih tinggi. Secara kualitatif dapat disebutkan bahwa tepi akan terdeteksi pada distribusi histogram suhu dengan dua puncak atau histogram bimodal. Algoritme mendeteksi populasi piksel pada histogram citra termasuk unimodal atau bimodal, dan jika dideteksi bimodal maka harus ditentukan threshold untuk memisahkan kedua populasi tersebut [15] [45].

Parameter rata-rata dan varian tiap populasi akan mudah dihitung jika threshold yang optimal diketahui. Meskipun threshold tidak diketahui dalam penelitian Cayula dan Cornillon [15], disimpulkan bahwa histogram hanya berada pada rentang nilai representasi suhu dalam citra skala keabuan 8-bit. Dengan fakta diatas threshold dimungkinkan memiliki nilai 1 hingga 255. Pencarian nilai threshold terbaik dapat dilakukan dengan estimasi parameter untuk setiap threshold yang dimungkinkan menggunakan turunan pertama dan atau kedua. Dikarenakan sumberdaya komputasi yang tinggi untuk citra 8-bit, proses dilakukan pada level window tumpang tindih $32 \times 32$ piksel [15].

Untuk menguji keterpaduan spasial dari window tumpang tindih digunakan algoritme pengukur tingkat kohesi dari tiap populasi, algoritme hanya dijalankan jika ditemukan histogram bimodal. Nilai kohesi tinggi dapat diartikan piksel yang tidak terlalu dekat dengan tepi, piksel disekitar piksel tersebut termasuk populasi yang sama. Dapat disimpulkan segmentasi spasial tiap populasi adalah valid dan benar adanya tepi pada setiap window [15].

Proses terakhir pada algoritme SIED untuk deteksi dan verifikasi tepi berada pada level lokal. Tepi yang ditemukan pada proses level window hanya menghasilkan piksel tepi independen. Dalam studi statistik kaitannya dengan front suhu, piksel tepi tersebut kurang memadai dan harus ada proses lebih lanjut untuk menghubungkan piksel tepi hingga membentuk kontur. Proses akan menyediakan algoritme deteksi front dengan menghubungkan piksel hingga membentuk kontur [15].

\section{Pemurnian Front dengan Geodesic Buffer}

Buffer adalah area dalam jarak maksimum radius dari sebuah titik pusat yang dihitung secara $360^{\circ}$ atau membentuk lingkaran dengan jari-jari berupa jarak maksimum radius yang masih relevan. Geodesic buffer memperhitungkan bentuk aktual permukaan bumi dalam melakukan buffer. Bentuk aktual bumi adalah ellipsoid atau lebih tepatnya geoid. Setiap geodesic buffer memperhitungkan lengkung bumi sehingga buffer akan berbentuk elips pada beberapa bagian spesifik peta berproyeksi 2 dimensi, dan akan berbentuk lingkaran pada seluruh globe. Dibandingkan dengan euclidean buffer menggunakan maksimal buffer sama $3.000 \mathrm{~km}$, Euclidean buffer akan bekerja dengan baik pada sistem koordinat kartesian 2 dimensi tetapi untuk aplikasi pada sistem koordinat bumi lebih tepat digunakan geodesic buffer [46].

Jarak maksimum klorofil-a terhadap front harus ditentukan untuk mempertahankan relevansi. Sebagai acuan digunakan hasil penelitian tentang radius titik potensi penangkapan ikan yang menyimpulkan bahwa jarak radius $5 \mathrm{~km}$ hingga $10 \mathrm{~km}$ adalah radius titik potensi penangkapan ikan yang masih relevan [16]. Front murni adalah titik pusat piksel sebuah front yang berada di dalam Geodesic buffer radius 10 $\mathrm{km}$ dari titik pusat klorofil-a.

\section{E. Evaluasi Performa}

Evaluasi pengukuran performa dari suatu algoritme deteksi obyek umumnya menggunakan akurasi dan error rate. Akurasi didefinisikan sebagai nilai kedekatan suatu hasil prediksi dengan nilai sebenarnya, sedangkan error rate adalah kebalikan dari akurasi yaitu nilai kesalahan hasil prediksi berbanding dengan nilai sebenarnya [47].

Penggunaan akurasi untuk mengukur performa dari hasil prediksi dapat menimbulkan bias, karena obyek yang diprediksi kesalahan dan nilai aktual nya adalah salah akan dihitung sebagai tambahan akurasi deteksi [48]. Untuk mendeteksi bias dari suatu prediksi digunakan Recall dan Precission. Recall atau Sensitivity dapat diartikan sebagai jumlah obyek yang benar-benar positif (true positive) berhasil terdeteksi oleh suatu algoritme berbanding dengan keseluruhan obyek positif (true positive dan false positive). Precission didefinisikan sebagai evaluasi kecenderungan suatu algoritme untuk menghasilkan 


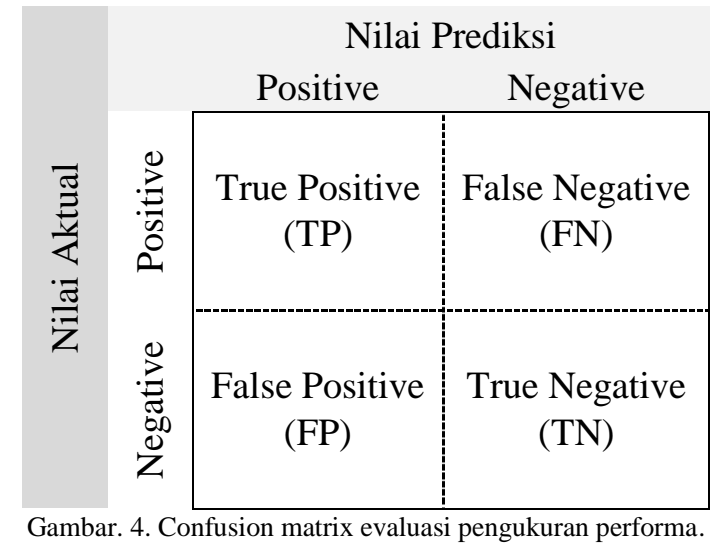

prediksi yang tepat tapi tidak sesuai nilai aktual (false positive) [47] [49]. Klasifikasi dari evaluasi pengukuran performa diformulasikan dalam confussion matrix seperti pada Gambar 4.

Dari informasi confusion matrix Gambar 4 dapat digunakan untuk pencarian nilai akurasi, recall dan precission dengan Persamaan 17 sampai dengan Persamaan 19 sebagai berikut:

$$
\begin{gathered}
A C C=\left(\frac{T P+T N}{T P+T N+F P+F N}\right) \cdot 100 \% \\
R E C=\left(\frac{T P}{T P+F N}\right) \cdot 100 \% \\
P R E C=\left(\frac{T P}{T P+F P}\right) \cdot 100 \%
\end{gathered}
$$

\section{HASIL DAN PEMBAHASAN}

\section{A. Modifikasi Perhitungan Threshold Optimal}

Perhitungan threshold optimal untuk setiap dataset dilakukan sesuai dengan Persamaan 1 hingga Persamaan 16. Algoritma Otsu tradisional efektif untuk digunakan pada citra fotografi. Algoritma Otsu membutuhkan masukan data sebaran intensitas piksel dalam 256 kelompok piksel (0-255). Sebaran intensitas kelas piksel citra grayscale yang dikonversi tidak pernah merata. Beberapa kelas piksel

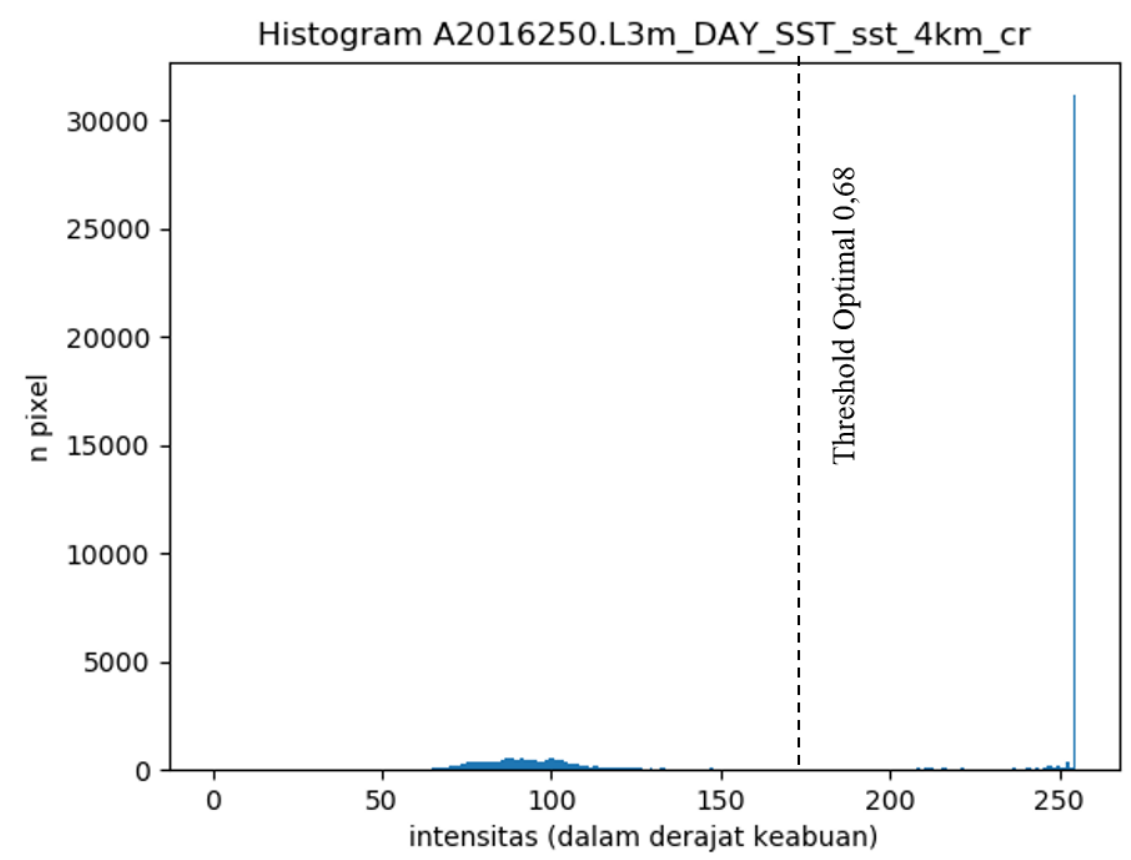

Gambar. 5. Metode Otsu tradisional dengan rentang histogram 0-255. 


\section{Jurnal ELTIKOM : Jurnal Teknik Elektro, Teknologi Informasi dan Komputer}

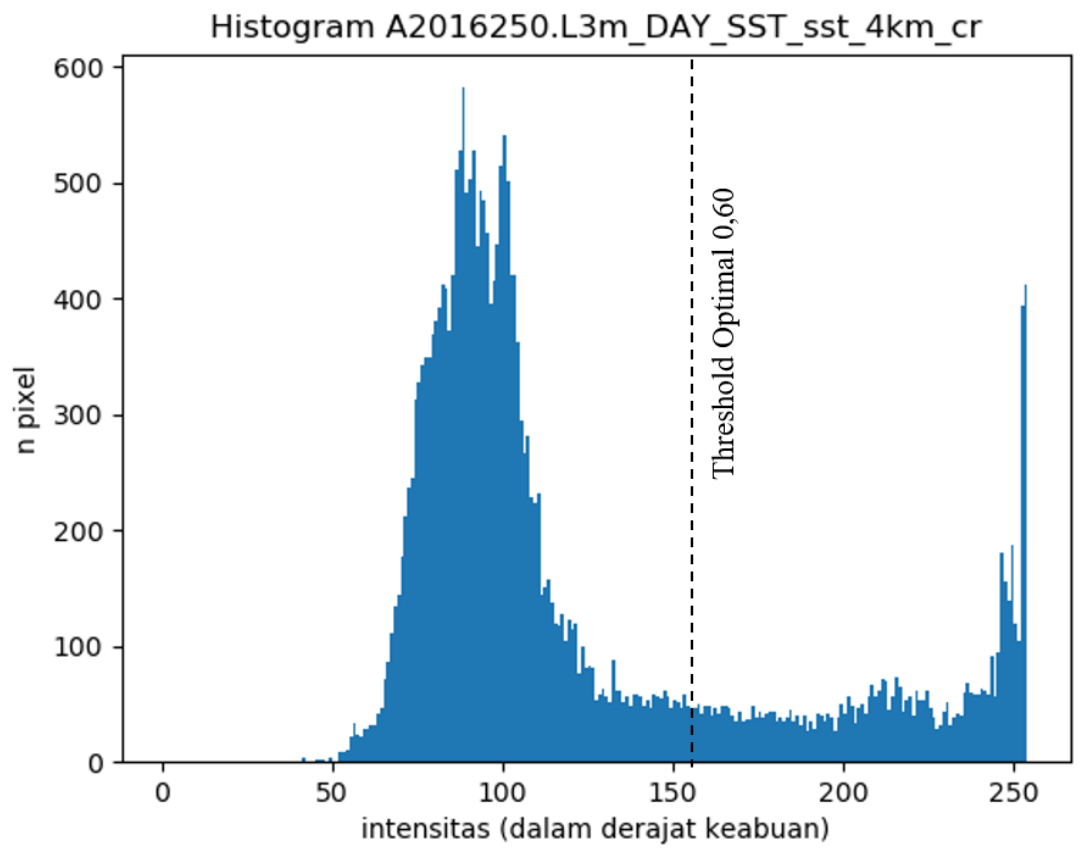

Gambar. 6. Modifikasi Metode Otsu rentang histogram 1-254.

bergeser dan mengakibatkan hilangnya beberapa distribusi kelas. Kelas intensitas piksel berkumpul hingga menjulang berbentuk bukit, dapat membentuk satu atau dua puncak di area tengah histogram. Untuk mengatasi hilangnya beberapa kelas piksel dan meratakan sebaran intensitas diperlukan normalisasi histogram yaitu mengambil nilai minimum pada histogram sebagai 0 , nilai maksimum sebagai 255, dan nilai diantaranya diskalakan dengan seimbang secara linier. Algoritme Otsu menggunakan filter Gaussian untuk mendistribusikan nilai diantara minimum dan maksimum yang merata agar normalisasi dapat bekerja dengan baik.

Dari Gambar 5 dapat dilihat bahwa nilai intensitas histogram berkumpul di titik maksimum (255) dan terlihat sedikit tumpukan data di tengah. Sifat alami dari dataset dengan referensi spasial adalah memiliki piksel NO_DATA. Konversi menjadi bentuk raster mengakibatkan piksel tanpa data berubah menjadi putih absolut (255) yang menjadi kerancuan pada perhitungan threshold. Untuk mendapatkan hasil yang valid maka nilai maksimum (255) dan minimum (0) dieliminasi dari perhitungan. Nilai minimum pada histogram adalah 1 dan nilai maksimum adalah 254, hasil dari modifikasi maksimum minimum dapat dilihat seperti pada Gambar 6. Modifikasi menghasilkan threshold optimal menjauhi putih absolut.

TABEL 2

HASIl PENCARIAN THREShold OPTIMAL UNTUK SETIAP CITRA

\begin{tabular}{lcc}
\hline \hline Dataset SST & Threshold Optimal & Front Terdeteksi \\
\hline A2016245.L3m_DAY_SST_sst_4km_cr.nc & 0,54296875 & 101 \\
A2016246.L3m_DAY_SST_sst_4km_cr.nc & 0,58203125 & 124 \\
A2016247.L3m_DAY_SST_sst_4km_cr.nc & 0,57812500 & 306 \\
A2016248.L3m_DAY_SST_sst_4km_cr.nc & 0,63281250 & 0 \\
A2016249.L3m_DAY_SST_sst_4km_cr.nc & 0,58984375 & 0 \\
A2016250.L3m_DAY_SST_sst_4km_cr.nc & 0,60546875 & 36 \\
A2016251.L3m_DAY_SST_sst_4km_cr.nc & 0,68359375 & 70 \\
A2016252.L3m_DAY_SST_sst_4km_cr.nc & 0,60546875 & 240 \\
A2016253.L3m_DAY_SST_sst_4km_cr.nc & 0,62890625 & 63 \\
A2016254.L3m_DAY_SST_sst_4km_cr.nc & 0,62109375 & 201 \\
A2016255.L3m_DAY_SST_sst_4km_cr.nc & 0,63671875 & 0 \\
A2016256.L3m_DAY_SST_sst_4km_cr.nc & 0,64062500 & 142 \\
A2016257.L3m_DAY_SST_sst_4km_cr.nc & 0,65234375 & 0 \\
A2016258.L3m_DAY_SST_sst_4km_cr.nc & 0,60937500 & 25 \\
A2016259.L3m_DAY_SST_sst_4km_cr.nc & 0,62500000 & 0 \\
A2016260.L3m_DAY_SST_sst_4km_cr.nc & 0,62109375 & 52 \\
A2016261.L3m_DAY_SST_sst_4km_cr.nc & 0,59375000 & 279 \\
A2016262.L3m_DAY_SST_sst_4km_cr.nc & 0,65234375 & 0 \\
A2016263.L3m_DAY_SST_sst_4km_cr.nc & 0,60546875 & 168 \\
A2016264.L3m_DAY_SST_sst_4km_cr.nc & 0,71093750 & 0 \\
A2016265.L3m_DAY_SST_sst_4km_cr.nc & 0,62500000 & 0 \\
\hline \hline
\end{tabular}




\section{Jurnal ELTIKOM : Jurnal Teknik Elektro, Teknologi Informasi dan Komputer}

Hasil perhitungan nilai threshold untuk setiap citra penelitian sebagaimana terlihat pada Tabel 2. Pada Tabel 2 terlihat pada beberapa citra tidak terdeteksi front, penelusuran lebih lanjut dilakukan dengan memberikan threshold 0,5 dan threshold 0,3 (nilai minimum yang diperbolehkan algoritme SIED). Seperti terlihat pada Tabel IV penggunaan threshold 0,5 tidak menghasilkan deteksi front begitu juga dengan threshold 0,3. Hasil penelusuran menunjukkan algoritme SIED berjalan hingga perhitungan kriteria untuk menentukan histogram bimodal atau unimodal. Nilai kriteria menunjukkan bahwa citra adalah unimodal sehingga algoritme SIED tidak dapat mendeteksi front.

\section{B. Hasil Analisis Pemurnian Front}

TABEL 3

PEMURNIAN GEODESIC BUFFER FRONT TERHADAP KLOROFIL-A

\begin{tabular}{|c|c|c|c|}
\hline Dataset SST dan Klorofil-a & Front Terdeteksi & Pemurnian Front & Deteksi Negatif \\
\hline A2016245... & 101 & 57 & 44 \\
\hline A2016246... & 124 & 3 & 121 \\
\hline A2016247... & 306 & 20 & 286 \\
\hline A2016248... & 0 & 0 & 0 \\
\hline A2016249... & 0 & 0 & 0 \\
\hline A2016250... & 36 & 26 & 10 \\
\hline A2016251... & 70 & 69 & 1 \\
\hline A2 $2016252 \ldots$ & 240 & 185 & 55 \\
\hline A2016253... & 63 & 0 & 63 \\
\hline A2016254... & 201 & 64 & 137 \\
\hline A2 $2016255 \ldots$ & 0 & 0 & 0 \\
\hline A2016256... & 142 & 54 & 88 \\
\hline A2016257... & 0 & 0 & 0 \\
\hline A2016258... & 25 & 4 & 21 \\
\hline A2016259... & 0 & 0 & 0 \\
\hline A2016260... & 52 & 48 & 4 \\
\hline A2016261... & 279 & 130 & 149 \\
\hline A2016262... & 0 & 0 & 0 \\
\hline A2016263... & 168 & 9 & 159 \\
\hline A2016264... & 0 & 0 & 0 \\
\hline A2016265... & 0 & 0 & 0 \\
\hline
\end{tabular}

Front terdeteksi dengan threshold optimal dan Klorofil-a tersaring direpresentasikan per satu piksel dalam posisi bujur dan lintang. Front dimurnikan dengan jarak buffer maksimal $10 \mathrm{~km}$ terhadap klorofila tersaring. Front di luar jarak buffer maksimal $10 \mathrm{~km}$, akan dianggap sebagai deteksi negatif.

Analisis Geodesic Buffer menggunakan klorofil-a tersaring terhadap front yang terdeteksi berhasil memurnikan front pada setiap citra. Satu dataset (A2016253...) tidak berhasil dimurnikan karena tutupan awan pada dataset klorofil-a terlampau tinggi. Hasil pemurnian front dan deteksi negatif akan digunakan dalam proses pengukuran performa dengan cara mengukur ketepatan titik deteksi (murni dan negatif) terhadap data aktual yaitu data respon balik peta prakiraan daerah penangkapan ikan. Hasil dari

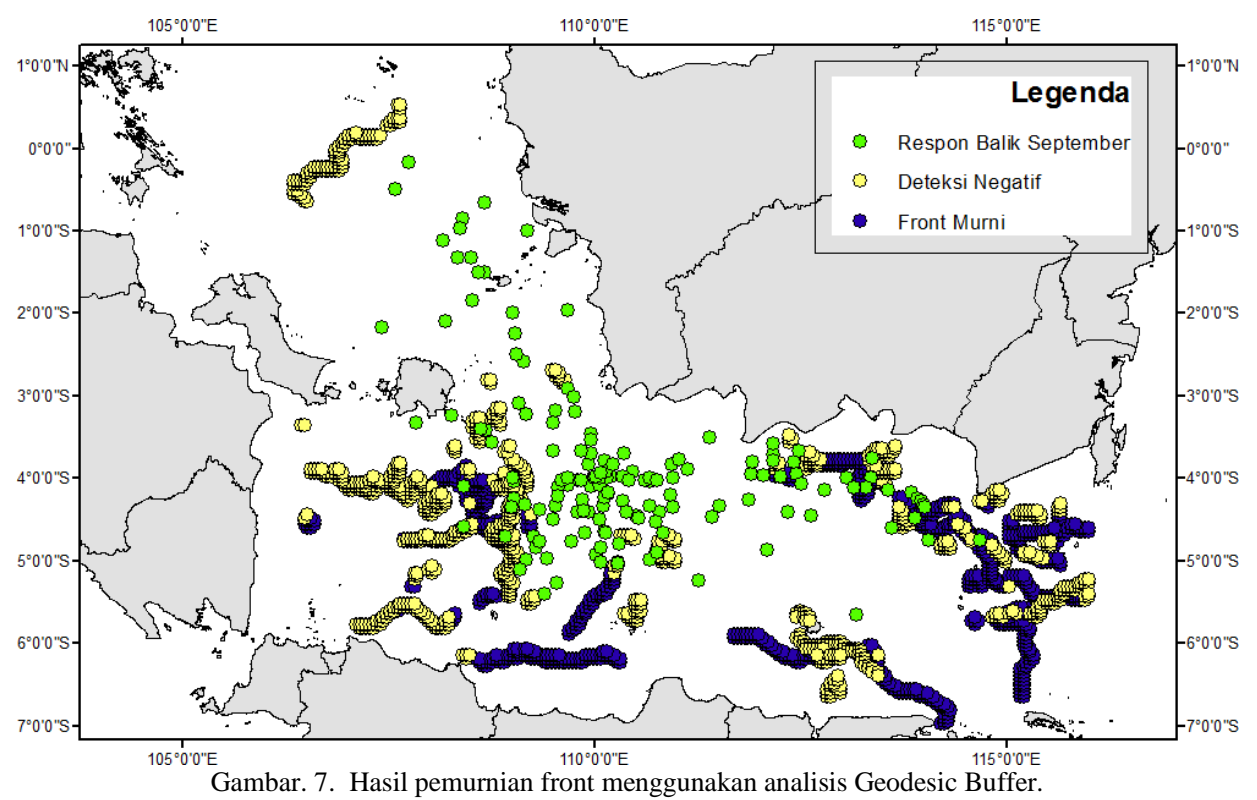




\section{Jurnal ELTIKOM : Jurnal Teknik Elektro, Teknologi Informasi dan Komputer}

keseluruhan analisis front dataset harian pada bulan September disatukan seperti terlihat pada Gambar 7. Penyatuan data dilakukan untuk menganalisis performa metode usulan dengan pencocokkan terhadap data aktual penangkapan.

\section{Perbandingan Dengan Metode Threshold Statis}

Metode penentuan front dengan threshold statis 0,5 dimurnikan dengan klorofil-a tersaring [17]. Front yang terdeteksi threshold statis 0,5 akan langsung dicocokkan dengan keberadaan klorofil-a tersaring pada titik yang bertepatan. Hasil dari keseluruhan analisis front metode threshold 0,5 dataset harian pada bulan September disatukan Penyatuan data dilakukan untuk menganalisis performa metode threshold 0,5 dengan pencocokkan terhadap data aktual penangkapan. Hasil dari analisis performa metode threshold 0,5 akan dibandingkan dengan analisis performa metode usulan.

TABEL 4

Perbandingan Hasil Metode Usulan Terhadap Metode Threshold Statis 0,5

\begin{tabular}{|c|c|c|c|c|c|c|c|c|}
\hline \multirow[b]{2}{*}{$\begin{array}{c}\text { Dataset SST dan } \\
\text { Klorofil-a }\end{array}$} & \multicolumn{4}{|c|}{ Threshold Adaptif } & \multicolumn{4}{|c|}{ Threshold Statis } \\
\hline & $\begin{array}{c}\text { Nilai } \\
\text { Threshold }\end{array}$ & $\begin{array}{c}\text { Front } \\
\text { Terdeteksi }\end{array}$ & $\begin{array}{l}\text { Pemurnian } \\
\text { Front }\end{array}$ & $\begin{array}{l}\text { Deteksi } \\
\text { Negatif }\end{array}$ & $\begin{array}{c}\text { Nilai } \\
\text { Threshold }\end{array}$ & $\begin{array}{c}\text { Front } \\
\text { Terdeteksi }\end{array}$ & $\begin{array}{l}\text { Pemurnian } \\
\text { Front }\end{array}$ & $\begin{array}{l}\text { Deteksi } \\
\text { Negatif }\end{array}$ \\
\hline A2016245... & 0,54 & 101 & 57 & 44 & 0,50 & 101 & 23 & 78 \\
\hline A2016246... & 0,58 & 124 & 104 & 20 & 0,50 & 124 & 46 & 78 \\
\hline A2016247... & 0,58 & 306 & 90 & 216 & 0,50 & 306 & 49 & 257 \\
\hline A2016248... & 0,63 & 0 & 0 & 0 & 0,50 & 0 & 0 & 0 \\
\hline A2016249... & 0,59 & 0 & 0 & 0 & 0,50 & 0 & 0 & 0 \\
\hline A2016250... & 0,60 & 36 & 26 & 10 & 0,50 & 36 & 14 & 22 \\
\hline A2016251... & 0,68 & 70 & 69 & 1 & 0,50 & 70 & 56 & 14 \\
\hline A2016252... & 0,61 & 240 & 185 & 55 & 0,50 & 240 & 124 & 116 \\
\hline A2016253... & 0,63 & 63 & 0 & 63 & 0,50 & 63 & 0 & 63 \\
\hline A2016254... & 0,62 & 201 & 64 & 137 & 0,50 & 280 & 78 & 202 \\
\hline A2016255... & 0,64 & 0 & 0 & 0 & 0,50 & 0 & 0 & 0 \\
\hline A2016256... & 0,64 & 142 & 54 & 88 & 0,50 & 234 & 38 & 196 \\
\hline A $2016257 \ldots$ & 0,65 & 0 & 0 & 0 & 0,50 & 0 & 0 & 0 \\
\hline A2016258... & 0,61 & 25 & 4 & 21 & 0,50 & 25 & 0 & 25 \\
\hline A2016259... & 0,63 & 0 & 0 & 0 & 0,50 & 0 & 0 & 0 \\
\hline A2016260... & 0,62 & 52 & 48 & 4 & 0,50 & 52 & 37 & 15 \\
\hline A2016261... & 0,59 & 279 & 130 & 149 & 0,50 & 279 & 92 & 187 \\
\hline A2016262... & 0,65 & 0 & 0 & 0 & 0,50 & 0 & 0 & 0 \\
\hline A2016263... & 0,61 & 168 & 57 & 111 & 0,50 & 168 & 39 & 129 \\
\hline A2016264... & 0,71 & 0 & 0 & 0 & 0,50 & 0 & 0 & 0 \\
\hline A2016265 .. & 0,63 & 0 & 0 & 0 & 0,50 & 0 & 0 & 0 \\
\hline
\end{tabular}

Dapat dilihat pada Tabel 4 perbedaan Front terdeteksi antara penggunaan threshold adaptif dengan threshold statis 0,5 hanya terdapat pada dataset A2016254... dan A2016256... total sejumlah 171 titik. Perbedaan tidak terlalu besar disebabkan oleh area analisis yang kecil yaitu 264 kolom $\times 216$ baris data. Metode pemurnian usulan menghasilkan total 888 front murni dan total deteksi negatif sejumlah 919 titik, sedangkan metode threshold statis 0,5 menghasilkan total 596 front murni dan total deteksi negatif sejumlah 1.382 titik.

\section{Pengukuran Performa}

Pengukuran performa dilakukan dengan parameter hasil pencocokkan titik deteksi hasil penelitian dan perbandingannya terhadap front threshold 0,5 . Parameter yang digunakan adalah sebagai berikut:

True Positive = jumlah titik front murni yang cocok dengan titik respon balik,

True Negative = jumlah titik deteksi negatif yang tidak cocok dengan titik respon balik,

False Positive = jumlah titik front murni yang tidak cocok dengan titik respon balik, dan

False Negative = jumlah titik deteksi negatif yang cocok dengan titik respon balik.

Hasil penyatuan seluruh deteksi front metode yang diusulkan dicocokkan dengan data aktual respon balik dan menghasilkan titik-titik sesuai dengan parameter confusion matrix seperti terlihat pada Gambar 8. Hasil dari pengukuran parameter untuk metode yang diusulkan dengan threshold optimal adalah sebagai berikut:

True Positive $=\mathrm{TP}=72$, 


\section{Jurnal ELTIKOM : Jurnal Teknik Elektro, Teknologi Informasi dan Komputer}

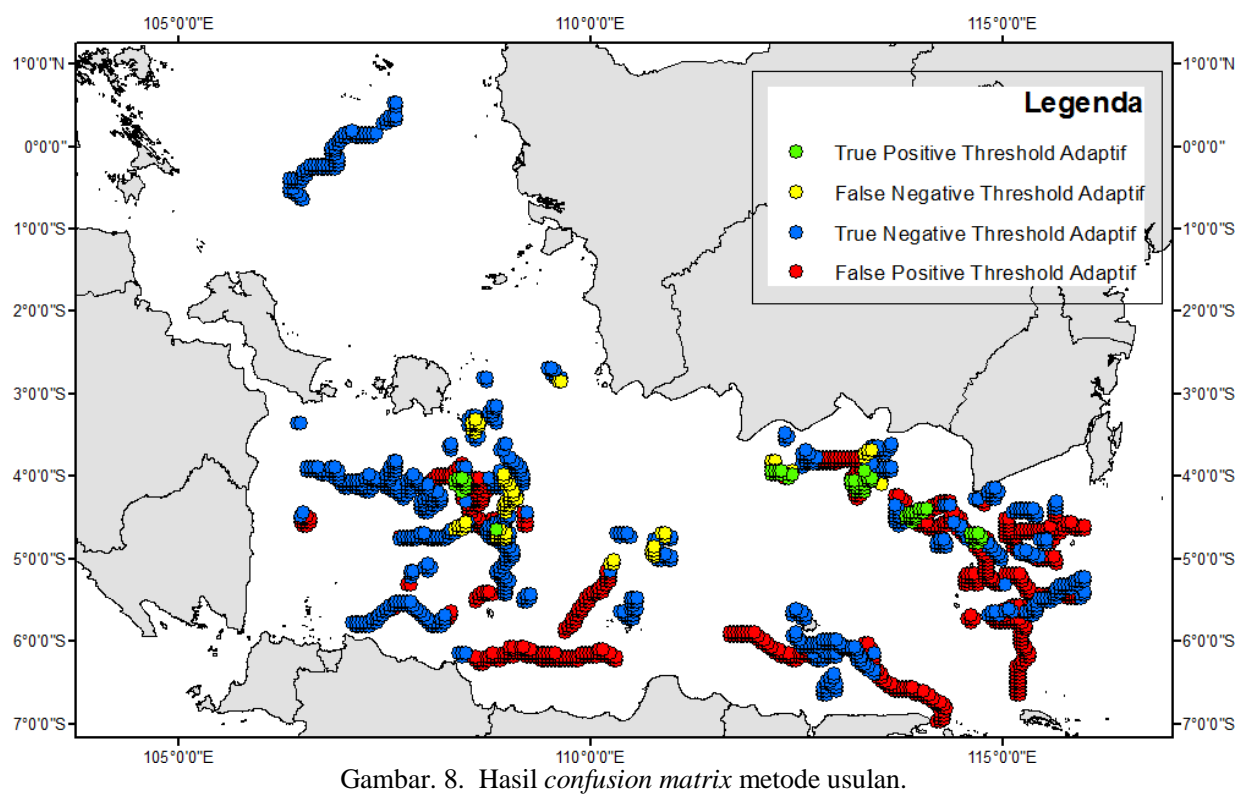

True Negative $=\mathrm{TN}=839$,

False Positive $=\mathrm{FP}=816$, dan

False Negative $=\mathrm{FN}=80$.

Performa hasil penelitian dengan threshold optimal didapatkan dengan nilai sebagai berikut:

Akurasi $=\left(\frac{T P+T N}{T P+T N+F P+F N}\right) \cdot 100 \%=\left(\frac{72+839}{72+839+816+80}\right) \cdot 100 \%=50,42 \%$,

Presisi $=\left(\frac{T P}{T P+F P}\right) \cdot 100 \%=\left(\frac{72}{72+816}\right) \cdot 100 \%=8,11 \%$,

Recall $=\left(\frac{T P}{T P+F N}\right) \cdot 100 \%=\left(\frac{72}{72+80}\right) \cdot 100 \%=47,37 \%$.

Sebagai perbandingan dilakukan pencocokkan hasil deteksi front metode threshold 0,5 dengan data aktual respon balik dan menghasilkan titik-titik sesuai dengan parameter confusion matrix seperti terlihat pada Gambar 9. Pengukuran performa terhadap deteksi front metode threshold statis 0,5 menghasilkan pengukuran parameter sebagai berikut:

True Positive $=\mathrm{TP}=45$,

True Negative $=\mathrm{TN}=1222$,

False Positive $=\mathrm{FP}=551$, dan

False Negative $=\mathrm{FN}=160$.

Performa deteksi front dengan threshold statis 0,5 didapatkan dengan nilai sebagai berikut:

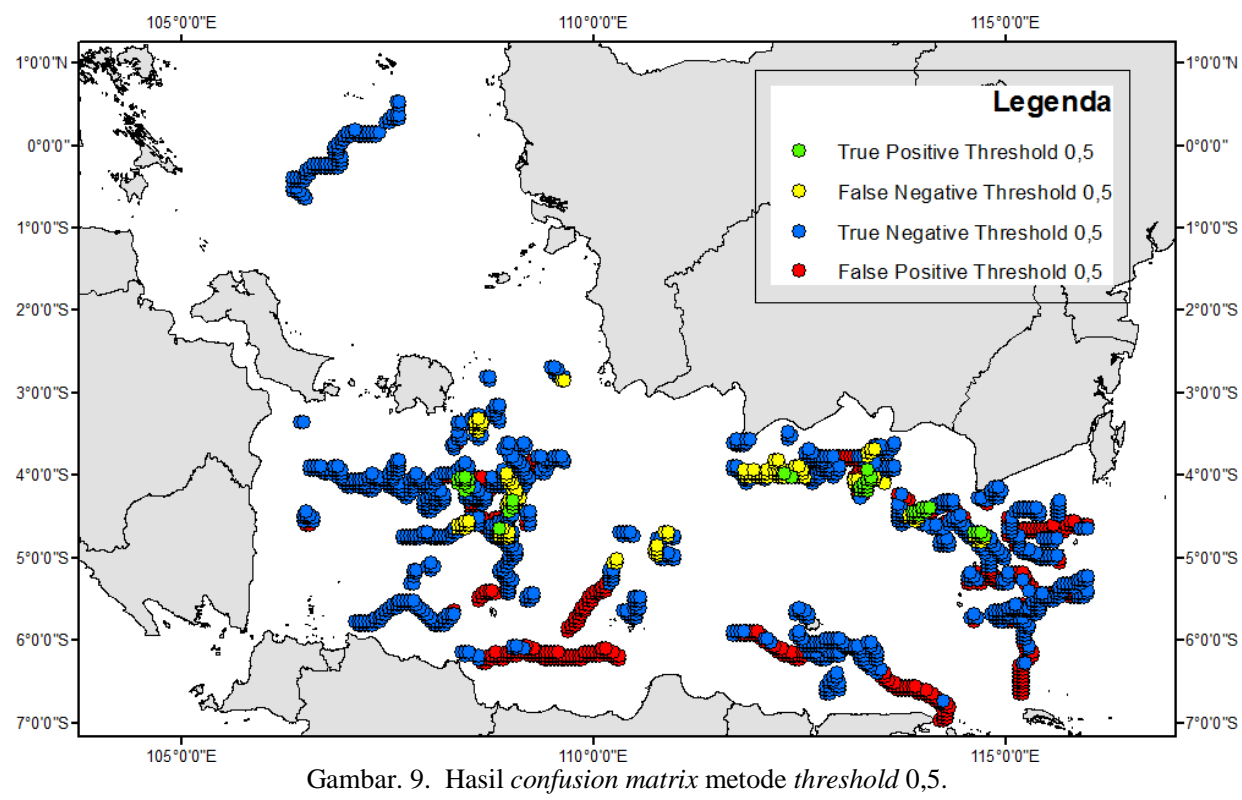




\section{Jurnal ELTIKOM : Jurnal Teknik Elektro, Teknologi Informasi dan Komputer}

$$
\begin{aligned}
& \text { Akurasi }=\left(\frac{T P+T N}{T P+T N+F P+F N}\right) \cdot 100 \%=\left(\frac{45+1222}{45+1222+551+160}\right) \cdot 100 \%=64,05 \% \\
& \text { Presisi }=\left(\frac{T P}{T P+F P}\right) \cdot 100 \%=\left(\frac{45}{45+551}\right) \cdot 100 \%=7,55 \% \\
& \text { Recall }=\left(\frac{T P}{T P+F N}\right) \cdot 100 \%=\left(\frac{45}{45+160}\right) \cdot 100 \%=21,95 \%
\end{aligned}
$$

Hasil pengukuran performa dari metode yang diusulkan dengan metode threshold statis 0,5 didapatkan nilai akurasi sebesar $64,05 \%$, lebih tinggi dibandingkan metode yang diusulkan yaitu $50,42 \%$. Lebih tingginya akurasi metode threshold statis dikarenakan nilai True Negative (TN) sejumlah 1.222 titik lebih banyak daripada nilai TN metode yang diusulkan sebesar 839. Nilai TN adalah titik yang dideteksi tidak ada ikan dan ketika dicocokkan dengan data respon balik memang benar tidak ada titik penangkapan yang sesuai sehingga nilai negatif adalah benar. Untuk mengukur performa parameter presisi dan recall menjadi lebih penting dibandingkan parameter akurasi yang memiliki bias tinggi.

Nilai presisi metode yang diusulkan yaitu $8,11 \%$ dapat diartikan bahwa metode akan menghasilkan 81 deteksi yang tepat sesuai nilai aktual, dari 1.000 deteksi front yang telah dimurnikan. Nilai presisi lebih baik daripada deteksi front dengan threshold statis 0,5 yang menghasilkan nilai presisi sebesar $7,55 \%$.

Pengukuran nilai recall untuk metode yang diusulkan menghasilkan nilai sebesar 47,37\%. Sebagai perbandingan metode deteksi front threshold statis 0,5 menghasilkan nilai recall $21,95 \%$. Recall pada penelitian adalah tingkat keberhasilan metode dalam menghasilkan deteksi front yang benar berbanding dengan seluruh titik aktual yang bertepatan dengan front murni dan deteksi negatif. Dengan kata lain metode yang diusulkan berhasil mendeteksi lebih banyak mendeteksi front murni yang bertepatan dengan data aktual sebanyak 72 titik dan kesalahan deteksi negatif yang ternyata titik penangkapan ikan pada data aktual sebanyak 80 titik. Nilai tersebut lebih baik dibanding metode threshold statis 0,5 yang hanya mendeteksi front murni sesuai data aktual sebanyak 45 titik dan kesalahan deteksi negatif yang ternyata titik penangkapan ikan pada data aktual sebanyak 160 titik.

\section{KESIMPULAN}

Berdasarkan hasil dan pembahasan metode yang diusulkan dalam penelitian dapat ditarik kesimpulan penggunaan threshold adaptif dan pemurnian dengan Geodesic Buffer hasil dari penelitian berhasil meningkatkan performa metode penentuan daerah potensi penangkapan ikan dengan presisi dan recall yang lebih baik dari metode sebelumnya. Penurunan akurasi sebesar 13,64\% terjadi karena metode yang diusulkan lebih sedikit menghasilkan deteksi negatif yang jika divalidasi terhadap data aktual akan memberikan nilai true negative lebih sedikit dibandingkan dengan metode sebelumnya yang lebih banyak menghasilkan deteksi negatif. Deteksi negatif yang terbukti benar-benar negatif memberikan nilai bias yang lebih tinggi terhadap akurasi. Nilai recall yang lebih tinggi 25,42\% membuktikan bahwa metode yang diusulkan mampu memberikan hasil deteksi front murni yang lokasinya tepat dengan data aktual dibanding metode sebelumnya. Peningkatan presisi sebesar 0,56\% menunjukkan kemampuan metode yang diusulkan dapat memberikan front murni lebih banyak daripada metode sebelumnya. Hasil analisis pengukuran performa membuktikan bahwa metode usulan berhasil meningkatkan performa metode deteksi daerah potensi ikan sebelumnya.

\section{DAFTAR PUSTAKA}

[1] Adnan, “Analisis Suhu Permukaan Laut dan Klorofil-A Data Inderaja Hubungannya dengan Hasil Tangkapan Ikan Tongkol (Euthynnus Affinis) di Perairan Kalimantan Timur," Amanisal, vol. 1, no. 1, hal. 1-12, 2010.

[2] R. Hamzah, T. Prayogo, dan S. Marpaung, "Metode Penentuan Titik Koordinat Zona Potensi Termal Front Suhu Permukaan Laut ( Method of Determination Points Coordinate for Potential Fishing Zone Based on Detection of Thermal Front Sea Surface Temperature )," J. Penginderaan Jauh, vol. 13, no. 2, hal. 97-108, 2016.

[3] D. Jatisworo, A. Murdimanto, dan K. Wikantika, "Peranan Teknologi Penginderaan Jauh Bagi Penangkapan Ikan di Indonesia (Studi Kasus Kabupaten Indramayu)," in Bunga Rampai Penginderaan Jauh Indonesia, 2012, hal. 123-137.

[4] D. Setiapermana, S. H. Santoso, dan Riyono, "Chlorofil Content In Relation to Physical Structure in East Indian Ocean," Oseanologi Indones. LIPI, vol. 25, hal. 13-29, 1992.

[5] N. Hendiarti et al., "Seasonal Variation of Pelagic Fish Catch Around Java," Oceanogr. Soc., vol. 18, no. 4, hal. 112-123, 2005.

[6] M. Firdaus, "Profil Perikanan Tuna dan Cakalang di Indonesia," MARINA, vol. 4, no. 1, hal. 23-32, 2018.

[7] R. J. Beamish, G. A. McFarlane, dan J. R. King, "Migratory patterns of pelagic fishes and possible linkages between open ocean and coastal ecosystems off the Pacific coast of North America," Deep. Res. Part II Top. Stud. Oceanogr., vol. 52, no. 5, hal. 739-755, 2005.

[8] A. S. Genisa, "Pengenalan Jenis-jenis Ikan Laut Ekonomi Penting di Indonesia," Oseana, vol. xxiv, no. 1, hal. 17-38, 1999. 


\section{Jurnal ELTIKOM : Jurnal Teknik Elektro, Teknologi Informasi dan Komputer}

[9] Indrayani, A. Mallawa, dan M. Zainuddin, "Penentuan Karakteristik Habitan Daerah Potensial Ikan Pelagis Kecil dengan PendekatanSpasial di Perairan Sinjai," e-Journal Progr. Pascasarj. Univ. Hasanuddin, vol. 12, no. 1, hal. 1-10, 2012.

[10] M. Zainuddin, "Skipjack Tuna in Relation To Sea Surface Temperature and Chlorophyll-a Concentration of Bone Bay Using Remotely Sensed Satellite Data," J. Ilmu dan Teknol. Kelaut. Trop., vol. 3, no. 1, 2011.

[11] M. Zainuddin, M. B. Selamat, A. Farhum, dan S. Hidayat, "Prediction of Potential Fishing Zones for Skipjack Tuna During the Northwest Monsoon Using Remotely Sensed Satellite Data," Ilmu Kelaut., vol. 22, no. 2, hal. 59-66, 2017.

[12] W. E. Rintaka dan E. Susilo, "Validation of potential fishing zone forecast using experimental fishing method in Tolo Bay, Central Sulawesi Province," IOP Conf. Ser. Earth Environ. Sci., vol. 137, no. 1, 2018.

[13] T. M. Lillesand, R. W. Kiefer, dan J. W. Chipman, "Remote sensing and image interpretation Wiley," New York, hal. 1-59, 1994.

[14] C. C. Wall, F. E. Muller-Karger, M. A. Roffer, C. Hu, W. Yao, dan M. E. Luther, "Satellite remote sensing of surface oceanic fronts in coastal waters off west-central Florida," Remote Sens. Environ., vol. 112, no. 6, hal. 2963-2976, 2008.

[15] J.-F. Cayula dan P. Cornillon, "Edge Detection Algorithm for SST Images," J. Atmos. Ocean. Technol., vol. 9, no. 1, hal. 67-80, 1992.

[16] B. Hasyim, Pengembangan dan Penerapan Informasi Spasial dan Temporal Zona Potensi Penangkapan Ikan Berdasarkan Data Penginderaan Jauh. Bogor: Crespent Press, 2015.

[17] D. Jatisworo dan A. Murdimanto, "Identifikasi thermal front di Selat Makassar dan Laut Banda," in Simposium Nasional Sains Geoinformasi III, 2013, hal. 226-232.

[18] E. R. Davies, Computer and Machine Vision: Theory, Algorithms, Practices, 4 ed. London: Elsevier, 2012.

[19] J. Kittler, J. Illingworth, dan J. Föglein, "Threshold Selection Based on a Simple Image Statistic," Comput. Vision, Graph. Image Process., vol. 30, no. 2, hal. 125-147, 1985.

[20] Y. Wu, Y. He, dan H. Cai, "Optimal threshold selection algorithm in edge detection based on wavelet transform," Image Vis. Comput., vol. 23, no. 13, hal. 1159-1169, 2005.

[21] J. Marcello, F. Eugenio, S. Estrada-Allis, dan P. Sangrà, "Segmentation and tracking of anticyclonic eddies during a submarine volcanic eruption using ocean colour imagery," Sensors (Switzerland), vol. 15, no. 4, hal. 8732-8748, 2015.

[22] L. Roa-Pascuali, H. Demarcq, dan A. E. Nieblas, "Detection of mesoscale thermal fronts from 4km data using smoothing techniques: Gradient-based fronts classification and basin scale application," Remote Sens. Environ., vol. 164, no. July, hal. 225-237, 2015.

[23] Y. Yang, J. Dong, X. Sun, R. Lguensat, M. Jian, dan X. Wang, “Ocean Front Detection from Instant Remote Sensing SST Images," IEEE Geosci. Remote Sens. Lett., vol. 13, no. 12, hal. 1960-1964, 2016.

[24] X. Sun, C. Wang, J. Dong, E. Lima, dan Y. Yang, "A Multiscale Deep Framework for Ocean Fronts Detection and Fine-Grained Location," IEEE Geosci. Remote Sens. Lett., vol. 16, no. 2, hal. 178-182, 2019.

[25] John Canny, “A Computational Approach To Edge Detection,” IEEE Trans. Pattern Anal. Mach. Intell., vol. 8, no. 6, hal. 679-714, 1986.

[26] G. Kirches, M. Paperin, H. Klein, C. Brockmann, dan K. Stelzer, "GRADHIST - A method for detection and analysis of oceanic fronts from remote sensing data," Remote Sens. Environ., vol. 181, hal. 264-280, 2016.

[27] V. Oerder, J. P. Bento, C. E. Morales, S. Hormazabal, dan O. Pizarro, "Coastal upwelling front detection off Central Chile (36.5-37 ${ }^{\circ}$ S) and spatio-temporal variability of Frontal characteristics," MDPI Remote Sens., vol. 10, no. 690, hal. 1-24, 2018.

[28] NASA, "PO.DAAC MODIS Level 3 Data User Guide," no. September 23. California Institute of Technology, hal. 1-52, 2015.

[29] P. J. Minnett, R. H. Evans, E. J. Kearns, dan O. B. Brown, "Sea-surface temperature measured by the Moderate Resolution Imaging Spectroradiometer (MODIS)," Int. Geosci. Remote Sens. Symp., vol. 2, no. July, hal. 1177-1179, 2002.

[30] W. E. Esaias et al., "An overview of MODIS capabilities for ocean science observations," IEEE Trans. Geosci. Remote Sens., vol. 36, no. 4, hal. 1250-1265, 1998.

[31] NASA, “MODIS Design.” [Daring]. Tersedia pada: https://modis.gsfc.nasa.gov/about/design.php. [Diakses: 26-Agu-2019].

[32] G. C. Feldman dan NASA, "Long-Wave Sea Surface Temperature (SST)." [Daring]. Tersedia pada: https://oceancolor.gsfc.nasa.gov/atbd/sst/. [Diakses: 19-Sep-2019].

[33] O. B. Brown dan P. J. Minnett, "MODIS Infrared Sea Surface Temperature Algorithm Algorithm Theoretical Basis Document," 1999.

[34] G. C. Feldman dan NASA, “Chlorophyll a (chlor_a)." [Daring]. Tersedia pada: https://oceancolor.gsfc.nasa.gov/atbd/chlor_a/. [Diakses: 22-Sep-2019].

[35] C. Proctor, "A. Manufacturer calibration and coefficients," hal. 1-4, 2012.

[36] Peraturan Menteri Kelautan Dan Perikanan Republik Indonesia Nomor 48/PERMEN-KP/2014 Tentang Log Book Penangkapan Ikan. 2014.

[37] A. F. Torres-Monsalve dan J. Velasco-Medina, "Hardware implementation of ISODATA and Otsu thresholding algorithms," in 2016 21 st Symposium on Signal Processing, Images and Artificial Vision, STSIVA 2016, 2016.

[38] S. Guiming dan S. Jidong, "Remote sensing image edge-detection based on improved Canny operator," in Proceedings of 2016 8th IEEE International Conference on Communication Software and Networks, ICCSN 2016, 2016, hal. 652-656.

[39] S. I. Syafi'i, R. T. Wahyuningrum, dan A. Muntasa, "Segmentasi Obyek Pada Citra Digital Menggunakan Metode Otsu Thresholding," J. Inform., vol. 13, no. 1, 2016.

[40] N. Otsu, "A Threshold Selection Method from Gray-Level Histograms," IEEE Trans. Syst. Man. Cybern., vol. 9, no. 1, hal. 62-66, 1979.

[41] D. Putra, "Binerisasi citra tangan dengan metode otsu," Teknol. Elektro, vol. 3, no. 2, hal. 11-13, 2004.

[42] Y. Chang dan P. Cornillon, "A comparison of satellite-derived sea surface temperature fronts using two edge detection algorithms," Deep. Res. Part II Top. Stud. Oceanogr., vol. 119, hal. 40-47, 2015.

[43] J. Kittler dan J. Illingworth, "Minimum Error Thresholding," Pattern Recognit., vol. 19, no. 1, hal. 41-47, 1986.

[44] J. Kittler dan D. Pairman, "Contextual Pattern Recognition Applied to Cloud Detection and Identification," IEEE Trans. Geosci. Remote Sens., vol. GE-23, no. 6, hal. 855-863, 1985.

[45] S. Cho, R. Haralick, dan S. Yi, "Improvement of kittler and illingworth's minimum error thresholding," Pattern Recognition, vol. 22, no. 5. hal. 609-617, 1989.

[46] D. Flater, "Understanding Geodesic Buffering Correctly use the Buffer tool in ArcGIS," ArcUser, hal. 33-37, 2011.

[47] T. Saito dan M. Rehmsmeier, "The Precision-Recall Plot Is More Informative than the ROC Plot When Evaluating Binary Classifiers on Imbalanced Datasets," PLoS One, no. March, hal. 1-21, 2015.

[48] D. M. Powers, "Evaluation : From precision, recall and F-measure to ROC , informedness, markedness \& correlation," J. Mach. Learn. Technol., vol. 2, no. 1, hal. 37-63, 2015.

[49] B. Özdemir, S. Aksoy, S. Eckert, M. Pesaresi, dan D. Ehrlich, "Performance measures for object detection evaluation," Pattern Recognit. Lett., vol. 31, no. 10, hal. 1128-1137, 2010. 